\title{
EFEKTIVITAS PEMBELAJARAN BERBASIS MASALAH DALAM MENULIS KARANGAN EKSPLANASI KELAS V
}

\author{
Sri Nurhayati, M. Ridlwan, Dwijani Ratna Dewi \\ Universitas Muhammadiyah Surabaya \\ srinurhayati@gmail.com
}

ABSTRAK

ABSTRACT
Tujuan penelitian : 1. Untuk membuktikan perbedaan kemampuan siswa yang mendapat dan yang tanpa menggunakan strategi pembelajaran berbasis masalah, 2. Untuk membuktikan keefektifan strategi pembelajaran berbasis masalah dari hasil menulis karangan eksplanasi. Metode penelitian : jenis penelitian menggunakan pendekatan kuantitatif dengan jenis penelitian A. Jenis A yang digunakan adalah A semu (quasi experimental), dengan desain control group pretest posttest. Populasi dan Sampel : populasi 187 siswa, sedangkan sampel kelas V A (kelas eksperimen) 36 siswa, sampel kelas V B (kelas kontrol) 36 siswa. Teknik pengumpulan data berdasarkah hasil tes dan nontes. Teknik analisi data: uji normalitas, uji homogenitas, uji-t, hipotesis statistik, dan analisi SWOT. Simpulan: terdapat perbedaan yang signifikan. Mean kelompok B 75,05, kelompok A 79,05. Nilai t = 2,171 , df 37 dan nilai $P=0,036$. Nilai $P$ lebih kecil dari taraf signifikansi $5 \%(0,036<0,05)$. Terdapat perbedaan yang signifikan kelompok B dengan kelompok A, 2. Hasil perbandingan uji-t pada skor prates dan pascates kelompok B dan kelompok A mengalami peningkatan, tetapi kelompok A mengalami peningkatan lebih besar. Rata-rata skor pascates kelompok A 79,05, rata-rata skor prates 71,70, rata-rata skor pascates kelompok B 75,05, dari ratarata skor prates 72,21 . Kata Kunci : Pembelajaran Berbasis Masalah, Karangan
Eksplanasi

Objectives of the study: 1 . To prove the difference on students' ability who did not get and use the problem-based learning strategy, 2. To prove the effectiveness of problem-based learning strategy from writing explanation. Research method: the type of this research used quantitative approach with type of research A. Type A used is quasi (quasi experimental), with control group pretest posttest design. Population and Sample: the population consisted of 187 students, while sample from class V A (experiment class) 36 students, sample from class V B (control class) 36 students. Data collection techniques are based on test and non-test results. Data analysis techniques: normality test, homogeneity test, t-test, statistical hypothesis, and SWOT analysis.Conclusion: there are significant differences. Mean of group B is 75.05, group A is 79.05. tValue is $=2.171$, df 37 and Pvalue $=0.036$. The value of $\mathrm{P}$ is smaller than $5 \%(0.036<0.05)$ of significance level. There was a significant difference of group B with group A. 2. The 
comparisonresult of t-test on pretest and posttest score of group B and group A was increased, but group A experienced a greater increase. The average score of group A posttestwas 79.05, the mean score of pretest was 71.70, the mean score of group B score 75.05, from the average score of 72.21 .

Keywords: Problem Based Learning, Explanation

PENDAHULUAN

Kegiatan menulis dalam pembelajaran bahasa Indonesia pada Kurikulum 2013 kelas V terdapat pada kompetensi inti dan kompetensi dasar 4.2 yaitu menyusun karangan hasil observasi, tanggapan deskriptif, eksposisi, karangan eksplanasi, dan cerita pendek. Permasalahan yang terjadi, pembelajaran menulis terkadang menjadi hal yang kurang diminati siswa. Banyak anggapan dari siswa bahwa menulis merupakan hal yang sulit. Selain itu, pada umumnya pembelajaran menulis saat ini masih dengan pola pembelajaran konvensional. Misalnya, pertama siswa disuruh membaca beberapa bacaan tentang suatu karangan. Kedua, guru menyampaikan materi pelajaran sesuai dengan pokok-pokok materi pelajaran. Ketiga, guru memberi kesempatan kepada siswa untuk bertanya apabila ada hal-hal yang kurang jelas. Keempat, guru mengulas pokok-pokok materi pelajaran yang telah disampaikan. Kelima, guru meminta siswa menulis karangan tersebut, sehingga membuat siswa bosan dan kurang menarik perhatian.

Di samping permasalahan di atas, guru dalam mengajar dengan pendekatan pembelajaran saintifik sesuai kurikulum 2013 masih memerlukan pelatihan dan perbaikan, karena kurikulum 2013 belum lama diterapkan. Sudah seharusnya guru menggunakan strategi pembelajaran yang tepat untuk mengajarkan pembelajaran menulis kepada siswa, agar kegiatan belajar mengajar lebih menarik.

Dari latar belakang masalah yang terjadi dalam pembelajaran menulis karangan dalam kurikulum 2013, peneliti memilih strategi pembelajaran berbasis masalah dalam pembelajaran menulis karangan eksplanasi. Strategi pembelajaran berbasis masalah sudah ada dalam kurikulum 2013, seperti dalam buku karangan Untuk itu, peneliti terdorong untuk meneliti keefektifan strategi pembelajaran berbasis masalah, karena strategi ini menuntut siswa untuk menemukan dan memecahkan sendiri masalah yang ada. Misalnya, pertama guru mengajukan suatu masalah. Kedua, siswa melakukan penyelidikan terkait masalah. Ketiga, siswa mengumpulkan informasi dan berdiskusi untuk memecahkan masalah. Keempat, siswa menulis karangan eksplanasi berdasarkan masalah yang ada. Kelima, siswa membaca atau mempresentasikan hasil Karangan eksplanasinya. Strategi pembelajaran berbasis masalah dalam pembelajaran kurikulum 2013 masih memerlukan adanya pemantauan perkembangan, keefektifan, dan efisiensinya. Penelitian-penelitian terdahulu, menguji keefektifan strategi pembelajaran berbasis masalah sesuai pembelajaran kurikulum 
2006, sedangkan penelitian ini sesuai pembelajaran kurikulum 2013.

Berdasarkan hal tersebut, tujuan penelitian ini adalah sebagai berikut.

1. Untuk mendeskripsikan perbedaan kemampuan siswa menulis karangan eksplanasi antara yang mendapat pembelajaran menggunakan strategi pembelajaran berbasis masalah dengan yang mendapat pembelajaran tanpa strategi pembelajaran berbasis masalah.

2. Untuk mendeskripsikan keefektifan strategi pembelajaran berbasis masalah dari hasil menulis karangan eksplanasi.

Penelitian serupa pernah dilakukan oleh Rani Wulan Harsanto (2014) dengan judul "Keefektifan Metode Pembelajaran Berbasis Masalah pada Pembelajaran Menulis Naskah Drama Siswa Kelas XI SMA Negeri 1 Sleman”. Simpulan dari penelitian tersebut adalah pembelajaran menulis naskah drama menggunakan metode pembelajaran berbasis masalah lebih efektif dibandingkan dengan pembelajaran tanpa metode pembelajaran berbasis masalah.

Selanjutnya, Aliansyah (2013) juga pernah melakukan penelitian serupa dengan judul "Keefektifan Metode Pembelajaran Berbasis Masalah dalam Pembelajaran Menulis Argumentasi Siswa Kelas X SMA Negeri 1 Godean Yogyakarta”. Simpulan dari penelitian tersebut adalah hasil penghitungan uji-t untuk sampel bebas berupa $t_{\text {hitung }}$ sebesar 2,608 dengan 61 dan nilai $\mathrm{P}$ sebesar 0,011 sehingga nilai $\mathrm{P}$ lebih kecil dari $0,05(\mathrm{P}<0,05)$ menunjukkan bahwa pembelajaran menulis argumentasi menggunakan metode pembelajaran berbasis masalah lebih efektif.

Menurut Barrow (dalam Huda, 2013:271), pembelajaran berbasis masalah sebagai pembelajaran yang diperoleh melalui proses menuju pemahaman akan resolusi suatu masalah. Masalah tersebut dipertemukan pertama kali dalam proses pembelajaran. Menurut Ridwan Abdullah Sani (2014:127), pembelajaran berbasis masalah merupakan pembelajaran yang penyampaiannya dilakukan dengan cara menyajikan suatu permasalahan, mengajukan pertanyaan-pertanyaan, memfasilitasi penyelidikan, dan membuka dialog. Sedangkan Arend (dalam Soetjipto dan Sri Mulyantini Soetjipto, 2008:41), mengungkapkan bahwa esensi pembelajaran berbasis masalah menyuguhkan berbagai situasi bermasalah yang autentik dan bermakna kepada siswa, yang dapat berfungsi sebagai batu loncatan untuk investigasi dan penyelidikan.

Dari beberapan pendapat di atas, dapat dirangkum bahwa pembelajaran berbasis masalah adalah pembelajaran yang menuntut siswa berpikir dan menemukan sendiri solusi terhadap permasalahan tersebut dengan pemahaman yang dimilikinya dan melibatkan teknologi dalam proses belajar.

Dalam pembelajaran bahasa Indonesia pada Kurikulum 2013 yang berbasis karangan, bahasa Indonesia diajarkan bukan sekedar sebagai pengetahuan bahasa, melainkan sebagai karangan yang berfungsi untuk menjadi sumber aktualisasi diri penggunanya pada 
nonkarangan sosial-budaya akademis. Seperti karangan eksplanasi yang berfungsi untuk menjelaskan hubungan logis proses terjadinya suatu fenomena atau peristiwa alam, teknologi dan proses sosial. Semakin banyak jenis karangan yang dikuasai siswa, semakin banyak pula struktur berpikir yang dapat digunakannya dalam kehidupan sosial.

Menurut Wong (2002:132), karangan eksplanasi adalah suatu penjelasan yang menceritakan bagaimana dan mengapa hal-hal terjadi dalam bidang ilmiah dan teknis. Sedangkan Knapp dan Watkins (2005:125), mengungkapkan genre karangan eksplanasi sebagai salah satu fungsi dasar bahasa untuk memahami dunia. Proses penjelasan dalam genre karangan ini digunakan untuk mengungkapkan urutan kejadian yang logis berkaitan dengan fungsi fisik lingkungan, sebagaimana memahami dan menginterpretasi ide-ide dan proses sosial serta intelektual.

\section{METODE}

Peneliti menggunakan pendekatan kuantitatif dengan jenis penelitian A. A adalah suatu cara untuk mencari hubungan sebab akibat (hubungan kausal) antara dua faktor yang sengaja ditimbulkan oleh peneliti dengan mengeliminasi atau mengurangi atau menyisihkan faktor-faktor lain yang mengganggu (Arikunto, 2010:9). Dengan demikian, dapat dipahami bahwa penelitian A dilakukan untuk mengetahui pengaruh perlakuan tertentu atau untuk melihat akibat suatu perlakuan. Jenis A yang digunakan adalah A semu (quasi experimental), dengan desain control group pretest posttest. Adapun desain control group pretest posttest menurut Arikunto (2010:125) adalah :

\begin{tabular}{|cccc|}
\hline $\mathrm{E}$ & $0_{1}$ & $\mathrm{X}$ & $0_{2}$ \\
\cline { 2 - 4 } $\mathrm{K}$ & $0_{3}$ & $\mathrm{X}$ & $0_{4}$ \\
\hline
\end{tabular}

Gambar 1. Desain Penelitian

Keterangan :

E : Kelompok A.

$\mathrm{K} \quad$ : Kelompok B.

$0_{1}$ dan $0_{2}$ : Prates kelompok A dan kelompok B.

$0_{3}$ dan $0_{4}$ : Pascates kelompok A dan kelompok B.

$\mathrm{X} \quad$ : Treatment atau perlakukan.

Sebagai sampel penelitian yaitu kelas V A sebagai kelompok kelas eksperimen dengan jumlah siswa sebanyak 36 anak, terdiri dari 22 siswa laki, dan 14 siswa perempuan dan kelas V B sebagai kelompok kelas kontrol dengan jumlah siswa sebanyak 36 anak, terdiri dari 18 siswa laki, dan 18 siswa perempuan. Kedua kelas tersebut terdiri dari siswa-siswa yang homogen.

Teknik pengumpulan data yang akan digunakan dalam penelitian ini adalah bentuk tes uraian. Bentuk tes uraian yang dimaksud adalah hasil siswa dalam menulis karangan eksplanasi. Tes akan dilakukan sebanyak dua kali, yaitu sebelum perlakuan dan sesudah perlakuan. Tes pertama disebut prates. Prates digunakan 
untuk mengukur kemampuan dasar siswa. Tes kedua disebut pascates. Pascates digunakan untuk mengetahui kemampuan siswa menulis karangan eksplanasi dengan penerapan strategi pembelajaran berbasis masalah.

Selanjutnya, teknik analisis data menggunakan uji normalitas, homogenitas, dan uji-t. Data uji normalitas dalam penelitian ini dilakukan pada skor prates dan skor pascates, baik kelompok A maupun kelompok B. Data dinyatakan berdistribusi normal apabila taraf signifikansi lebih dari $5 \%$ atau 0,05 . Penghitungan uji normalitas menggunakan bantuan SPSS versi 16. Data homogenitas diperoleh dari skor prates dan pascates kelompok A maupun kelompok B. Data dinyatakan homogen apabila taraf signifikansi lebih dari $5 \%$ atau 0,05. Penghitungan uji homogenitas menggunakan bantuan program komputer SPSS versi 20. Analisis data dalam penelitian ini menggunakan uji-t, yaitu uji-t sampel bebas dan sampel berhubungan. Uji-t sampel bebas dalam penelitian ini adalah skor prates kelompok satu dengan yang lain maupun skor pascates. Uji-t sampel berhubungan dalam penelitian ini adalah skor prates dan pascates, serta skor prates dan pascates. Data dinyatakan signifikan apabila nilai P kurang dari 5\% atau 0,05. Penghitungan uji-t menggunakan bantuan SPSS versi 20.

\section{PEMBAHASAN Deskripsi Penerapan Penggunaan Strategi Pembelajaran Berbasis Masalah}

Pembelajaran menulis karangan eksplanasi merupakan salah satu pembelajaran yang membutuhkan pikiran kritis dari siswa. Dalam hal ini, strategi pembelajaran berbasis masalah dapat berguna. Strategi ini membantu siswa untuk dapat mengembangkan kemampuan berpikirnya. Di dalam pembelajaran dengan strategi pembelajaran berbasis masalah, siswa diajarkan untuk menghubungkan antara apa yang mereka pelajari dengan bagaimana pengetahuan tersebut akan dimanfaatkan atau diaplikasikan dalam situasi yang baru. Siswa akan diajarkan bagaimana menyelesaikan suatu masalah.

Penggunaan strategi pembelajaran berbasis masalah pada pembelajaran menulis karangan eksplanasi diterapkan pada kelompok A. Strategi pembelajaran berbasis masalah digunakan pada perlakuan 1 sampai perlakuan 4 dengan topik yang berbedabeda. Penerapan penggunaan strategi pembelajaran berbasis masalah dalam pembelajaran menulis karangan eksplanasi dilakukan oleh guru mata pelajaran bahasa Indonesia.

Adapun langkah-langkah pembelajaran menulis karangan eksplanasi dengan strategi pembelajaran berbasis masalah. Pertama : Guru membuka pembelajaran dan melakukan apersepsi terkait dengan pembelajaran menulis karangan eksplanasi. Setelah itu, guru menjelaskan tujuan pembelajaran dan kegunaan strategi Pembelajaran Berbasis Masalah dalam pembelajaran menulis Karangan Eksplanasi; Kedua : Guru menayangkan sebuah video sesuai dengan topik yang akan ditulis siswa. Siswa mengamati suatu masalah yang terdapat dalam video tersebut dan menanyakan 
hal-hal yang belum dipahami. Siswa mengumpulkan data dan berdiskusi untuk memperoleh informasi terkait penjelasan masalah dan pemecahan masalah. Kemudian, siswa membuat karya karangan eksplanasi tentang proses terjadinya masalah yang ada, sesuai pembelajaran menulis karangan eksplanasi menggunakan strategi pembelajaran berbasis masalah. Setelah itu, siswa mempresentasikan hasil menulis karangan eksplanasi; Ketiga : Siswa bersama dengan guru menyimpulkan pembelajaran mengenai menulis karangan eksplanasi dengan strategi pembelajaran berbasis masalah yang sudah dilakukan. Kemudian, siswa melakukan refleksi terkait pembelajaran yang baru berlangsung dan menyimak informasi mengenai rencana tindak lanjut pembelajaran. Hal ini terlihat dari kreativitas pengembangan topik dan deretan penjelasan yang disampaikan oleh siswa dalam tulisan karangan eksplanasi, struktur karangan dan penggunaan ciri bahasa karangan eksplanasi juga sudah digunakan siswa dengan baik.

Pembelajaran menulis karangan eksplanasi dengan strategi pembelajaran berbasis masalah mampu mengembangkan kemampuan berpikir siswa dan memberikan kemudahan dalam menulis karangan eksplanasi. Strategi pembelajaran ini merupakan strategi pembelajaran yang menyenangkan dan membuat siswa tidak bosan pada saat pembelajaran menulis karangan eksplanasi. Pembelajaran pada kelompok A atau kelompok eksperimen lebih kondusif dan membuat siswa aktif pada proses pembelajaran menulis karangan eksplanasi dengan menggunakan strategi pembelajaran berbasis masalah. Hal ini juga terlihat pada hasil menulis siswa yang mampu mengembangkan topik dan penyampaian deretan penjelasan dengan lebih baik.

Proses pembelajaran menulis karangan eksplanasi kelompok A atau kelompok eksperimen berbeda dengan kelompok B atau kelompok kontrol. Langkah-langkah pembelajaran kelompok B atau kelompok kontrol. Pertama : Guru membuka pembelajaran dan melakukan apersepsi terkait dengan pembelajaran menulis karangan eksplanasi. Setelah itu, guru menjelaskan tujuan pembelajaran; Kedua : Guru meminta siswa menulis karangan eksplanasi. Siswa mencari materi di perpustakaan atau internet sesuai topik yang akan ditulis. Kemudian, siswa membuat karya karangan eksplanasi sesuai topik berdasarkan materi yang diperolehnya. Setelah itu, siswa mempresentasikan hasil menulis karangan eksplanasi; Ketiga : Siswa bersama dengan guru menyimpulkan pembelajaran mengenai menulis karangan eksplanasi. Kemudian siswa melakukan refleksi terkait pembelajaran yang baru berlangsung dan menyimak informasi mengenai rencana tindak lanjut pembelajaran. Topik yang digunakan pada kelompok B sama dengan kelompok A.

\section{Deskripsi Kondisi Awal Kemampuan Menulis Karangan Eksplanasi pada Kelompok B dan Kelompok A}

Kondisi awal kedua kelompok dalam penelitian ini diketahui dengan melakukan prates keterampilan menulis karangan 
eksplanasi. Peneliti mengumpulkan data menggunakan instrumen penelitian berupa pedoman penyekoran tes menulis karangan eksplanasi, sesuai buku guru kurikulum 2013. Dari hasil pengumpulan data tersebut diperloleh skor prates kelompok B dan kelompok A. Dalam pemberian skor hasil tulisan siswa baik skor tes awal maupun skor tes akhir terdapat beberapa aspek penilaian, yaitu.

1. Aspek isi, meliputi : kreativitas pengembangan topik dan penyampaian deretan penjelas;

2. Aspek organisasi;

3. Aspek kosakata;

4. Aspek penggunaan bahasa; dan

5. Aspek mekanik.

Untuk menghasilkan skor tulisan karangan eksplanasi, yang pertama dilakukan adalah menganalisis tulisan karangan eksplanasi siswa berdasarkan kriteria penilaian yang ada. Skor tertinggi yang diperoleh kelompok B pada saat prates sebesar 70 dan skor terendah 55, sedangkan pada saat pascates skor tertinggi yang diperoleh kelompok B sebesar 85 dan skor terendah 64. Skor tertinggi yang diperoleh kelompok A pada saat prates sebesar 70 dan skor terendah 56, sedangkan pada saat pascates skor tertinggi yang diperoleh kelompok A sebesar 88 dan skor terendah sebesar 71. Skor rata-rata (mean) antara skor prates kelompok B dan kelompok A mengalami peningkatan. Pada saat prates, skor ratarata (mean) kelompok B 61,53 sedangkan pada saat pascates sebesar 74,56. Pada kelompok A, skor rata-rata (mean) pada saat prates sebesar 63,58, sedangkan pada saat pascates sebesar 81,47. Setelah didapatkan data tersebut, kemudian dilanjutkan dengan analisis data menggunakan uji-t. Analisis data tersebut dilakukan untuk membandingkan skor prates kelompok B dengan kelompok A. Analisis data pada skor prates bertujuan untuk mengetahui kemampuan awal menulis karangan eksplanasi dari kedua kelompok.

Sedangkan analisis menggunakan uji-t diperoleh nilai t sebesar -1,076, dengan df 70 pada taraf signifikansi 5\%. Selain itu, diperoleh nilai $P$ sebesar 0,286 . Nilai t tersebut lebih kecil dari nilai P 0,705 atau nilai $t:-1,076<\mathrm{p}: 0,381$. Demikian hasil uji-t pada skor prates tidak menunjukkan perbedaan kemampuan menulis karangan eksplanasi antara kelompok B dengan kelompok A. Dengan demikian, keadaan awal antara kelompok B dan kelompok A adalah sama.

Berdasarkan hasil tes awal kemampuan menulis karangan eksplanasi siswa, masih ditemukan beberapa faktor kelemahan siswa, baik kelompok B maupun kelompok A dalam pembelajaran menulis karangan eksplanasi. Adapun beberapa kelemahan siswa adalah sebagai berikut : Siswa masih kesulitan untuk mengembangkan topik tulisan. Walaupun terdapat beberapa siswa yang sudah cukup baik dalam menuliskan pernyataan umum sesuai topik bahasan, namum pengembangan deretan penjelas masih 
kurang lancar. Pengembangan topik dan deretan penjelasan juga kurang terperinci; Deretan penjelasan yang disampaikan siswa kurang rinci dan lengkap, bahkan terkadang kurang sesuai dengan topik bahasan; Dalam menulis karangan eksplanasi, masih banyak siswa yang kurang tepat dalam pemilihan kosakata; Penggunaan bahasa masih kurang efektif; dan Sering ditemukan kesalahan mekanik dalam tulisan karangan eksplanasi siswa yang meliputi kesalahan penggunaan tanda baca dan ejaan.

\section{Perbedaan Kemampuan Menulis Karangan Eksplanasi antara Siswa yang Mengikuti Pembelajaran dengan Menggunakan Strategi Pembelajaran Berbasis Masalah dan Siswa yang Mengikuti Pembelajaran Tidak Menggunakan Strategi Pembelajaran Berbasis Masalah}

Hasil prates kemampuan menulis karangan eksplanasi kelompok B dan kelompok A tidak ada perbedaan kemampuan menulis, karena kelompok B maupun kelompok A sama-sama belum mendapatkan perlakuan. Setelah prates dilakukan, kedua kelompok tersebut mendapatkan perlakuan. Kelompok A dalam pembelajaran menulis karangan eksplanasi diajar menggunakan strategi pembelajaran berbasis masalah, sedangkan kelompok B diajar tanpa menggunakan strategi pembelajaran berbasis masalah.

Uji-t skor prates keterampilan menulis karangan eksplanasi kelompok B dan kelompok A dilakukan untuk mengetahui ada tidaknya perbedaan keterampilan menulis karangan eksplanasi awal antara kedua kelompok tersebut. Setelah kelompok B dan kelompok A mendapatkan perlakuan, selanjutnya diukur kemampuan akhir menulis karangan eksplanasi dengan pascates. Pascates yang dilakukan berupa tes menulis karangan eksplanasi dengan topik yang sama saat prates. Skor pascates tersebut kemudian dianalisis menggunakan bantuan program komputer SPSS versi 16.

Uji-t data pascates keterampilan menulis karangan eksplanasi kelompok B dan kelompok A dilakukan untuk mengetahui ada tidaknya perbedaan keterampilan menulis awal antara kedua kelompok tersebut. Hasil menunjukkan bahwa nilai t sebesar 2,171 dengan df 70 pada taraf signifikansi 5\%. Selain itu, diperoleh nilai $\mathrm{P}$ sebesar 0,036 . Nilai $\mathrm{p}<$ dari taraf signifikansi yang menunjukan bahwa terdapat perbedaan yang signifikan kemampuan menulis karangan eksplanasi antara kelompok A dan kelompok B. Uji-t data prates dan pascates keterampilan menulis karangan eksplanasi kelompok B dilakukan untuk mengetahui perbedaan keterampilan menulis karangan eskplanasi siswa kelompok B. Hasil perhitungan menunjukkan bahwa nilai t adalah -12,470 dengan df 35 diperoleh nilai $\mathrm{P}$ sebesar 0,005 .Nilai $\mathrm{P}$ lebih kecil dari taraf signifikansi $5 \%$ $(0,005<0,05)$ menunjukkan adanya perbedaan keterampilan menulis karangan eksplanasi siswa kelompok B atau kelompok kontrol antara sebelum dan sesudah mendapatkan perlakuan tanpa strategi pembelajaran berbasis masalah.Uji-t prates dan pascates keterampilan menulis karangan eksplanasi kelompok A dilakukan 
untuk mengetahui perbedaan keterampilan menulis karangan eksplanasi siswa kelompok A.

Hasil perhitungan menunjukkan bahwa nilai t adalah sebesar 17,683 dengan df 35 pada taraf signifikansi 5\% diperoleh nilai $\mathrm{P}$ sebesar 0,000. Nilai P lebih kecil dari taraf signifikansi 5\% $(0,000<$ $0,05)$ menunjukkan adanya perbedaan keterampilan menulis karangan eksplanasi siswa kelompok A antara sebelum dan sesudah mendapat perlakuan dengan strategi pembelajaran berbasis masalah. Hasil analisis uji-t skor prates dan pascates kelompok B dan kelompok A menunjukkan bahwa terjadi peningkatan keterampilan menulis karangan eksplanasi yang dialami oleh kedua kelompok tersebut. Namun, peningkatan pada kelompok A lebih tinggi dari kelompok B.

Skor mean kelompok B saat prates sebesar 61,73 dan skor mean saat pascates sebesar 74,56. Hal ini menunjukkan bahwa terjadi peningkatan keterampilan menulis karangan eksplanasi kelompok B sebesar 13,03. Skor mean kelompok A saat prates sebesar 63,58 dan skor mean saat pascates sebesar 81,47. Hal ini menunjukkan bahwa terjadi peningkatan keterampilan menulis karangan eksplanasi kelompok A yang lebih tinggi, sebesar 17,89. Berdasarkan hasil analisis tersebut dapat disimpulkan bahwa strategi pembelajaran berbasis masalah efektif digunakan dalam pembelajaran menulis karangan eksplanasi. Tulisan karangan eksplanasi kelompok A setelah mendapatkan perlakuan, yaitu dengan menggunakan strategi pembelajaran berbasis masalah dalam pembelajaran menulis karangan eksplanasi terdapat peningkatan yang signifikan. Siswa yang menggunakan strategi pembelajaran berbasis masalah memiliki kreativitas mengembangkan topik dalam menulis karangan eksplanasi. Informasi yang disajikan lebih kompleks, pernyataan umum tersampaikan dengan baik, dan deretan penjelasan sudah runtut dalam menjelaskan suatu proses peristiwa alam. Tulisan karangan eksplanasi kelompok B juga mengalami peningkatan setelah mendapatkan perlakuan, meskipun tidak menggunakan strategi pembelajaran berbasis masalah. Namun, tulisan pascates kelompok $\mathrm{B}$ belum mampu mengembangkan topik bahasan dengan rinci. Kemudian terdapat beberapa pemilihan kosakata dan penggunaan bahasa yang kurang efektif.

\section{Tingkat Keefektifan Strategi Pembelajaran Berbasis Masalah}

Tingkat keefektifan penggunaan strategi pembelajaran berbasis masalah pada pembelajaran menulis karangan eksplanasi diketahui dari perbandingan nilai rata-rata prates dan pascates kelompok B dan kelompok A. Hasil pengujian tersebut menunjukkan bahwa penggunaan strategi pembelajaran berbasis masalah efektif digunakan dalam pembelajaran menulis karangan eksplanasi. Peningkatan kemampuan akhir dalam menulis karangan eksplanasi, lebih tinggi kelompok A yang menggunakan strategi pembelajaran berbasis masalah. 
Penggunaan strategi pembelajaran berbasis masalah dapat membantu siswa menemukan masalah dan menyelesaikan masalah tersebut. Strategi pembelajaran berbasis masalah mendorong siswa melakukan penyelidikan, mengkritisi masalah yang ada, mengumpulkan data dan berdiskusi, guna memperoleh informasi terkait penjelasan masalah serta pemecahan masalah. Jadi, strategi ini membantu siswa untuk dapat mengembangkan kemampuan berpikirnya karena siswa diajarkan bagaimana menyelesaikan suatu masalah. Melalui strategi pembelajaran berbasis masalah, siswa kelompok A dapat menulis karangan eksplanasi dengan lebih baik dibandingkan dengan kelompok B. Hal ini terlihat dari hasil tulisan siswa dalam menulis karangan eksplanasi dan penskoran menggunakan pedoman penilaian karangan eksplanasi sesuai buku Guru Kurikulum 2013.

Oleh karena itu, dapat disimpulkan bahwa dalam pembelajaran menulis karangan eksplanasi penggunaan strategi pembelajaran berbasis masalah lebih efektif daripada tidak menggunakan strategi pembelajaran berbasis masalah.

Dalam penelitian ini dapat diketahui bahwa penggunaan strategi pembelajaran berbasis masalah lebih efektif digunakan dalam pembelajaran menulis karangan eksplanasi. Hal ini ditunjukkan dengan hasil pada kelompok A yang memiliki nilai lebih tinggi daripada kelompok $\mathrm{B}$, setelah diberikan perlakuan. Maka dari itu, penggunaan strategi pembelajaran berbasis masalah efektif digunakan dalam pembelajaran menulis karangan eksplanasi.

Selama penelitian berlangsung, ditemukan beberapa kendala-kendala dalam penelitian ini, yaitu : Penelitian ini terbatas pada pembelajaran keterampilan menulis karangan eksplanasi siswa kelas V dengan dua kelas, yaitu kelas A sebanyak 20 siswa dan kelas B sebanyak 19 siswa. Jadi, belum tentu mendapatkan hasil dan keefektifan penggunaan strategi pembelajaran berbasis masalah yang sama jika dilakukan penelitian di kelas lain; Seharusnya penelitian dimulai sejak awal karangan diajarkan, yaitu memahami karangan eksplanasi. Namun ketika penelitian ini dilakukan, guru sudah memberikan materi memahami karangan eksplanasi, sehingga penelitian ini mulai dilakukan saat kegiatan menyusun karangan eksplanasi. Akan tetapi, hal ini tidak menjadi kendala yang berarti, karena topik penelitian sesuai dengan materi yang akan diajarkan kepada siswa, yaitu menulis karangan eksplanasi.

Terdapat perbedaan yang signifikan antara siswa kelompok A atau kelompok eksperimen yang mendapat pembelajaran menulis karangan eksplanasi dengan strategi pembelajaran berbasis masalah dengan siswa kelompok B atau kelompok kontrol yang mendapat pembelajaran menulis karangan eksplanasi tanpa menggunakan strategi pembelajaran berbasis masalah. Perbedaan terlihat bahwa mean keterampilan menulis karangan siswa kelompok B sebesar 75,05, sedangkan kelompok A sebesar 79,05. Perbedaan ini juga dibuktikan dengan analisis hasil uji-t : diperoleh nilai t sebesar 
2,171 dengan df 37 dan nilai $\mathrm{P}$ sebesar 0,036. Nilai $\mathrm{P}$ lebih kecil dari taraf signifikansi 5\% $(0,036<0,05)$. Dengan demikian, dapat diketahui terdapat perbedaan hasil keterampilan menulis karangan eksplanasi yang signifikan antara kelompok B dengan kelompok A.

Penggunaan strategi pembelajaran berbasis masalah dalam pembelajaran menulis karangan eksplanasi lebih efektif dibandingkan pembelajaran tanpa menggunakan strategi pembelajaran berbasis masalah. Keefektifan ditandai dari hasil perbandingan uji-t, yaitu skor kedua kelompok mengalami peningkatan kelompok A mengalami peningkatan lebih besar dengan rata-rata skor pascates sebesar 79,05, dari rata-rata skor prates sebesar 71,70, sedangkan rata-rata skor pascates kelompok B sebesar 75,05, dari rata-rata skor prates sebesar 72,21. Hal ini membuktikan bahwa strategi pembelajaran berbasis masalah lebih efektif digunakan dalam pembelajaran menulis karangan eksplanasi.

\section{DAFTAR PUSTAKA}

Aliansyah. 2013. Keefektifan Metode Pembelajaran Berbasis Masalah dalam Pembelajaran Menulis Argumentasi Siswa Kelas X SMA Negeri 1 Godean Yogyakarta. Yogyakarta:Universitas Negeri Yogyakarta.

Arikunto, Suharsimi. 2010. Prosedur Penelitian Suatu Pendekatan Praktik. Jakarta:Rineka Cipta.

Dalman. 2012. Menulis Karya Ilmiah. Jakarta:Raja Grafindo Persada.

Gultom, Pestauli. 2014. Pengaruh Penerapan Model Pembelajaran Berbasis Masalah Terhadap Kemampuan Menulis Teks Eksplanasi Siswa Kelas VII SMP Santo Ignasius Medan Tahun Pembelajaran 2013/2014. Medan:Universitas Negeri Medan.

Harsanto, Rani Wulan. 2014. Keefektifan Metode Pembelajaran Berbasis Masalah pada Pemelajaran Menulis Naskah Drama Siswa Kelas XI SMA Negeri 1 Sleman. Yogyakarta:Universitas Negeri Yogyakarta
Huda, Miftahul. 2013. Model-Model Pembelajaran. Yogyakarta:Pustaka Pelajar.

Iskandarwassid dan Dadang Sunendar. 2009. Strategi Pembelajaran Bahasa. Bandung:Remaja Rosdakarya.

Jogiyanto. 2005. Sistem Informasi Strategik untuk Keunggulan Kompetitif. Yogyakarta:Andi Offset.

Kementerian Pendidikan dan Kebudayaan. 2013a. Bahasa Indonesia: Wahana Pengetahuan. Jakarta:Kementerian Pendidikan dan Kebudayaan.

Knapp, Peter and Watkins Megan. 2005. Genre, Text, Grammar:Technologies for Teaching and Assessing Writing. Australia:University of New South Wales Press.

Muslimin. 2011. Perlunya Inovasi dalam Pembelajaran Bahasa dan Sastra Indonesia. Jurnal Bahasa dan Sastra Indonesia (online). Vol. 1, No. 1. Diakses dari : http//repository.ung.ac.id pada 20 April 2017. 
Nurgiyantoro, Burhan. 2012. Penilaian Pembelajaran Berbasis Kompetensi. Yogyakarta:BPFEYogyakarta.

2012. Statistik Terapan untuk Penelitian IlmuIlmu Sosial. Yogyakarta:Gadjah Mada University Press.

Nurjamal, Daeng, dkk. 2011. Terampil Berbahasa. Bandung:Alfabeta.

Pardiyono. 2007. Pasti Bisa! Teaching Genre-Based Writing. Yogyakarta:ANDI Yogyakarta.
Riduwan. 2010. Dasar-dasar Statistika. Bandung:Alfabeta.

Sani, Ridwan Abdullah. 2014. Pembelajaran Saintifik untuk Implementasi Kurikulum 2013. Jakarta:Bumi Aksara.

Soetjipto, Helly Prajitno dan Sri Mulyantini Soetjipto. 2008. Learning To Teach, terjemahan. Yogyakarta:Pustaka Pelajar.

Wong, Ruth. 2002. Teaching Text Types in The Singapore Primari Classroom. Singapore:Prentice Hall. 